\title{
PROBABILITY DENSITY FUNCTION OF THE NUMBER OF EMBRYOS COLLECTED FROM SUPEROVULATED NELORE BREED DONORS
}

\author{
Renato Travassos Beltrame ${ }^{1}$; Luis Gustavo Barioni2*; Celia Raquel Quirino ${ }^{1}$; Ozanival Dario \\ Dantas $^{2}$ \\ ${ }^{l}$ UENF/CCTA - Lab. de Reprodução e Melhoramento Genético Animal - Av. Alberto Lamego, 2000 - 28013-600 - \\ Campos dos Goytacazes, RJ - Brasil. \\ Embrapa Cerrados, Rod. Brasília-Fortaleza BR 020 - km 18 - 73301-970 - Planaltina, DF - Brasil. \\ *Corresponding Author <barioni@cpac.embrapa.br>
}

\begin{abstract}
Several models have been developed to evaluate reproductive status of cows through concentration of progesterone in milk, the effect of sex selection in the commercial production of herds and bioeconomic performance of the multiple ovulation and embryo transfer system in select herds. However, models describing the production of embryos in superovulated females have yet to be developed. A probability density function of the number of embryos collected by donors of the Nelore breed was determined. Records of 61,928 embryo collections from 26,767 donors from 1991 to 2005 were analyzed. Data were provided by the Brazilian Association of Creators of Zebu and Controlmax Consultoria e Sistemas Ltda. The probability density function of the number of viable embryos was modeled using exponential and gamma distributions. Parameter fitting was carried out for maximum likelihood using a non-linear gradient method. Both distributions presented similar level of precision: root mean square error $(\mathrm{RMSE})=0.0072$ and 0.0071 for the exponential and gamma distributions, respectively; both distributions are thus deemed suitable for representing the probability density function of embryo production by Nelore females.
\end{abstract}

Key words: zebu, cattle, reproduction, model

\section{FUNÇÃO DE DENSIDADE DE PROBABILIDADE DO NÚMERO DE EMBRIÕES PRODUZIDOS POR DOADORAS DA RAÇA NELORE}

\begin{abstract}
RESUMO: Diversos modelos têm sido desenvolvidos para avaliar o estado reprodutivo de vacas por meio da concentração de progesterona no leite, o efeito da seleção do sexo na produção comercial de rebanhos e o desempenho bioeconômico da ovulação múltipla e transferência de embriões em rebanhos selecionados. No entanto, modelos que descrevem a produção de embriões em fêmeas superovulados ainda têm de ser desenvolvidos. Uma função de densidade probabilidade para o número de embriões viáveis recuperados de doadoras da raça Nelore foi determinada. Dados de 61.928 coletas de 26.767 doadoras entre 1991 e 2005 foram analisados. Os resultados foram fornecidos pela Associação Brasileira de Criadores de Zebu (ABCZ) e pela empresa Controlmax Consultoria e Sistemas Ltda.. A densidade probabilidade do número de embriões viáveis foi modelada utilizando as funções exponencial e gama. A determinação dos parâmetros foi executada utilizando o critério de máxima verossimilhança em um método de gradiente não linear. Ambas distribuições permitiram similar nível de precisão: raiz do erro quadrático médio $(\mathrm{RMSE})=0.0072$ e 0.0071 para a distribuição exponencial e gama, respectivamente. Tanto a distribuição exponencial quanto a gama foram adequadas para representar a função de densidade probabilidade da produção de embriões para doadoras da raça Nelore.
\end{abstract}

Palavras-chave: zebu, vaca, reprodução, modelo

\section{INTRODUCTION}

Several models have been developed to evaluate reproductive status of cows through concentration of progesterone in milk (Friggens \& Chagunda, 2005), the effect of sex selection in the commercial production of herds (Hohenboken, 1999), and bioeconomic performance of the multiple ovulation and embryo transfer (MOET) system in select herds (Ruvuna et al., 1992a,b,c). However, models describing the production of embryos in superovulated females have yet to be developed.

Most reproduction models use the average value of the number of embryos for bioeconomic analysis (Ruvuna et al., 1992a,b,c; Friggens \& Chagunda, 1993; Cardoso et al., 1999; Hohenboken, 1999). How- 
ever, Beltrame et al. (2007) showed that economic evaluations based on average responses (deterministic simulations) of embryo production yield biased results. Therefore, in practical situations, decisions related to synchronization of the recipient females should be based on the expected distribution of the results.

Recently, some models have included stochasticity in the number generated (Ostergaard et al., 2005; Barioni et al., 2007; Beltrame et al., 2007). Most of them have assumed normal distribution, since the probability distribution of that variable seemed undetermined in the literature (Barioni et al., 2007; Beltrame et al., 2007).In this context, this study has the objective of identifying and fitting an adequate probability density function for the number of embryos generated by superovulated Nelore females, aiming to provide more reliable stochastic simulation models.

\section{MATERIAL AND METHODS}

\section{Determination of the frequency distribution}

Datasets were supplied by the Associação Brasileira dos Criadores de Zebu (Brazilian Zebu Cattle Breeders Association - ABCZ) and by a Controlmax Consultoria e Sistemas Ltda. (Controlmax Consulting anda Systems, Ltd.). The $\mathrm{ABCZ}$ dataset $\left(\mathrm{ABCZ}_{\mathrm{DS}}\right)$, includes all the communications of embryos collected from Nelore breed animals in Brazil from 1991 to 2005; the Controlmax dataset $\left(\mathrm{CM}_{\mathrm{DS}}\right)$, contained data collected from two embryo transfer centers and two farms. A total three hundred and fifty nine collections of embryos were analyzed.

Datasets were checked for consistency. Data of 254 collections were discarded on the grounds of incoherent date of collection, null fields or number of embryos higher than 35. Records of 61928 collections from 26767 donors remained in the dataset and were used to fit the models. The frequency of collections with no embryo produced was calculated through Equation 1.

$F_{0}=\frac{O_{0}, C M_{D S}}{N o b s_{C M_{D S}}}$,

where: $F_{0}$ is the frequency of superovulated donors with no embryo produced; $O_{0, C M}$ is the number of superovulated donors with no embryo produced and Nobs ${ }_{C M_{D S}}$ is the total number of collections in the $\mathrm{CM}_{\mathrm{DS}}$ dataset.

The frequencies of collections with number of embryos other than zero were defined using Equation 2, which corrects for the absence of collection with null observations in the $\mathrm{ABCZ}_{\mathrm{DS}}$ dataset.
$F_{0}=\frac{O_{n}, A B C Z_{D S}\left(1-F_{0}\right)}{N o b s_{A B C Z_{D S}}}$

where: $F_{n}$ is the frequency of collections with a given number (n) of embryos collected; $O_{n, A B C Z_{D S}}$ is the number of observations of collection with $\mathrm{n}$ embryos collected in the $\mathrm{ABCZ}$ dataset and $N o b s_{A B C Z_{D S}}$ is the total number of collections in the CM dataset.

\section{Model fitting}

To analyze data collected for using on stochastic analysis in a simulator, a theoretical distribution of the probabilities has to be identified. This distribution must represent, as reliable as possible, the behavior of the variable under study (Freitas Filho, 2001). A graphical comparison of the observed and estimated frequencies for different candidate models was carried out to select the most promising models (Figure 1).

The behavior of the studied data suggested that the negative exponential distribution $[E X(\lambda)]$ and the Gamma distribution $[\mathrm{G}(k, \lambda)]$ (Benjamin \& Cornell., 1970 ) would result in good data fit . A numerical optimization method was then used to identify the best value of the parameters.

Parameter estimation of the probability distributions were made through the least squares method using a maximum likelihood estimator for normally distributed data (Kostina, 2004). As there is no algorithm with undisputed efficacy for nonlinear estimation of parameters (Dantas et al., 2007), three algorithms were applied: (1) GRG2 (Lasdon et al. 1978); (2) Quasi-Newton (Press et al., 1990); and (3) the Downhill Simplex (Nelder \& Mead, 1965; Walsh, 1979; Press et al., 1990). Because the method is not functional for the adjustment of only one parameter, the third algorithm was applied only for fitting the Gamma model. The GRG2 method was applied using Microsoft Excel $2003^{\circledR}$ Solver. The last two methods were applied using Matlab ${ }^{1}$.

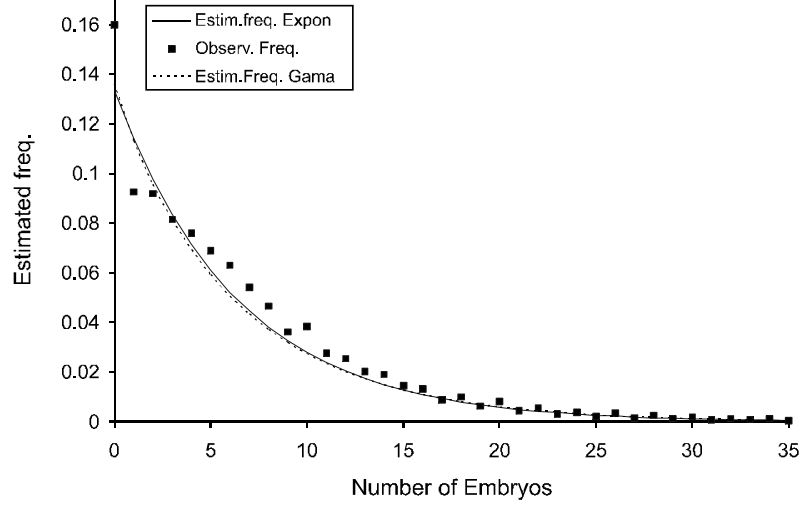

Figure 1 - Comparison between the observed and estimated frequencies obtained by the Exponential and Gama distributions.

${ }^{1}$ Official site of the applications program. Available at: <http://www.mathworks.com/>. Accessed in: 22 of May of 2007. 


\section{RESULTS AND DISCUSSION}

The average number embryos per collection (6.1) was found to be higher than that reported by Slenning et al. (1989), based on 39 published studies (4.4 \pm 2.8 ), but lower than that obtained by Baruselli et al. (2006) $(8.7 \pm 0.9)$, and close to values reported by Reichenbach $^{2}$ (2003), Merton et al. (2003) and Visintin et al. (1999) (5 6). The estimate of frequency of null collections, based on the $\mathrm{CM}_{\mathrm{DS}}$ was $16 \%$ (58 null collections in 359 records) which is intermediate to the values reported by Slenning et al. (1989) and by Baruselli et al. (2006), 8.2\%, and 20\%, respectively.

Both Gamma and Exponential distributions adjustments were significant ( $p<0.0001$; Tables 1 and 2). The coefficient of determination was high for both models $\left(\mathrm{R}^{2}=0.96\right.$ for both the Exponential and the Gamma distributions), therefore distributions explained most of the variance in the data. The standard errors of regression - 0.0072 and 0.0071 - for the Exponential and Gamma distributions, respectively, are acceptable for simulation purposes. Parameter estimates were $\lambda=0.156$ for the Exponential distribution and $\mathrm{k}=$ $0.947, \lambda=6.775$ for the Gamma distribution.

Although model fitting was completed with a large dataset, it was necessary to include an independent estimate of frequency of unsuccessful collections. There-

Table 1 - Analysis of variance for the Exponential distribution fitting.

\begin{tabular}{lccccc}
\hline FV & DF & SQ & QM & F & P> \\
\hline Regression & 1 & 0.0431 & 0.0425 & 827.12 & $0.0001 * *$ \\
Error & 34 & 0.0018 & $5 * 21^{-05}$ & - & - \\
Total & 35 & 0.0449 & - & - & - \\
R $^{2}$ & 0.96 & - & - & - & -
\end{tabular}

$\mathrm{FV}=$ Source of variation; $\mathrm{DF}=$ Degrees of freedom; $\mathrm{SQ}=$ Sum of errors; $\mathrm{QM}=$ Average Squared; $\mathrm{F}=$ Test of Significance; $* *=$ $p<0.01$ - high significance

Table 2 - Analysis of variance for the Gamma distribution fitting

\begin{tabular}{lccccc}
\hline FV & DF & SQ & QM & F & P> \\
\hline Regression & 1 & 0.0425 & 0.0425 & 831.92 & $0.0001 * *$ \\
Error & 34 & $1.74 \mathrm{E}^{-03}$ & $5 * 10^{-05}$ & - & - \\
Total & 35 & $4.42 \mathrm{E}^{-02}$ & - & - & - \\
$\mathrm{R}^{2}$ & 0.96 & - & - & - & - \\
\hline
\end{tabular}

$\overline{F V}=$ Source of variation $; \mathrm{DF}=$ Degrees of freedom; $\mathrm{SQ}=$ Sum of errors; $\mathrm{QM}=$ Average Squared; $\mathrm{F}=$ Test of Significance; $* *=$ $p<0.01$ - high significance

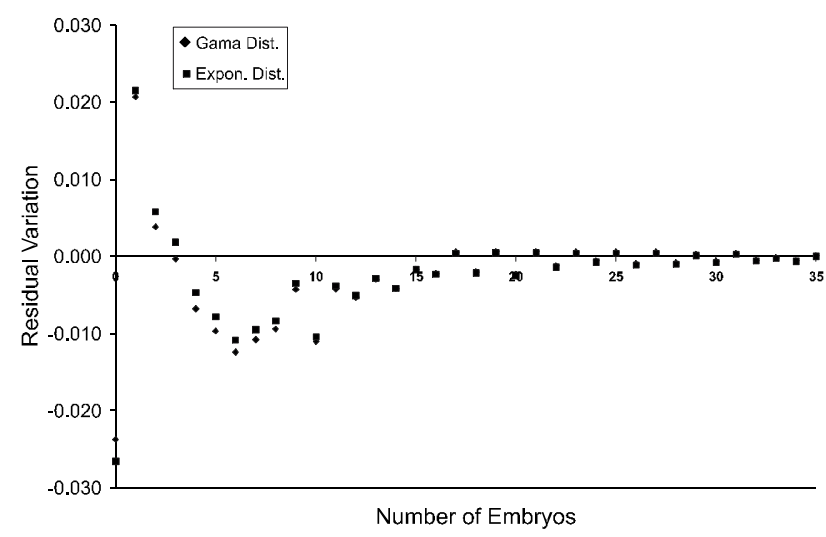

Figure 2 - Residual variation (estimated frequency - observed frequency) vs the number of embryos adjusted with the Gamma and Exponential distributions.

fore, the greater residual variation (Figure 2) for the frequencies of low number of embryos in the probability distribution may have resulted from the use of a different sample (the $\mathrm{CM}_{\mathrm{DS}}$ ) to originate the estimated frequencies of unsuccessful collections. Better parameter estimation would require a more comprehensive database reporting unsuccessful embryo collections.

Adjustments herein presented are deemed adequate for the purpose of giving a reference probability distribution function from which adjustments for specific situations may derive. The number of viable embryos per collection in the Nelore breed can be estimated by either the gamma or the exponential distributions, that should, instead of the normal distribution be used for simulations of that trait.

\section{ACKNOWLEDGEMENTS}

To the Brazilian Zebu Cattle Breeders Association ABCZ (Sr. Carlos Henrique Cavalari) and Controlmax Consultants and Systems Ltd. for permission to use their datasetsand CNPQ for financial support. To Dr. Euzébio Medrado da Silva, Embrapa CPAC, for suggestions related to probability density functions.

\section{REFERENCES}

BARIONI, L.G.; BELTRAME, R.T.; QUIRINO, C.R.; FERNANDES, D.R. Modelos determinista e estocástico em programas de transferência de embriões em bovinos. Archivos Latinoamericanos de Produccion Animal, v.15, p.107-113, 2007.

BARUSELLI, P.S.; SA FILHO, M.F.; MARTINS, C.M.; NASSER, L.F.; NOGUEIRA, M.F.G.; BARROS, C.M.; BÓ, G. Superovulation and embryo transfer in Bos indicus cattle. Theriogenology, v.65, p.77-88, 2006.

\footnotetext{
${ }^{2}$ It applies the method to solve on this value and parameter of agreement of the distribution. Reported by Horst-Dieter Reichenbach at the $17^{\text {a }}$ SBTE annual meeting, Fortaleza, Brazil, 2003).
} 
BELTRAME, R.T.; BARIONI, L.G.; MAESTRI, B.D.; QUIRINO, C.R. Economic optimization of the number of recipients in bovine embryo transfer programs. Scientia Agricola, v.64, p.221-226, 2007.

BENJAMIN, J.R.; CORNELl, C.A. Probability, statistics and decision for engineers. San Francisco: McGraw-Hill, 1970 $671 \mathrm{p}$.

CARDOSO, V.L.; NOGUEIRA, J.R.; ARENDONK, J.A.M.V. Optimal Replacement and insemination policies for holstein cattle in the southeastern region of Brazil: The effect of selling animals for production. Journal of Dairy Science, v.82, p.1449-1458, 1999.

DANTAS, O.D.; SILVA, E.M.; BARIONI, L.G.; OLIVEIRA, M.A.A.; LIMA, J.E.F. W. Comparação dos métodos GRG2 (solver do excel) e Downhill Simplex para a parametrização da função Beta. In: SIMPÓSIO BRASILEIRO DE PESQUISA OPERACIONAL, 39., Fortaleza, 2007. Anais. Fortaleza: SBPO, 2007. p.1802-1809.

FREITAS FILHO, P.J. Introdução a modelagem e simulação de sistemas. Florianópolis: Visual Books, 2001. 322p.

FRIGGENS, N.C.; CHAGUNDA, M.G.G. Prediction of the reproductive status of cattle on the basis of milk progesterone measures: model description. Theriogenology, v.64, p.155190,2005

HOHENBOKEN, W.D. Applications of sexed semen in cattle production. Theriogenology, v.52, p.1421-1433, 1999.

KOSTINA, E. Robust parameter estimation in dynamic systems. Optimization and Engineering, v.5, p.461-484, 2004.

LASDON, L.; WARREN, A.; JAIN, A.; RATNER, M. Design and testing of a generalized reduced gradient code for nonlinear programming. ACM Transactions on Mathematical Software, v.4, p.34-50, 1978.

MERTON, J.S.; ROOS, A.P.W.; MULLAART, E.; RUIGH, L.; KAAL, L.; VOS, P.L.A.M.; DIELEMAN, S.J. Factors affecting oocyte quality and quantity in commercial application of embryo technologies in the cattle breeding industry. Theriogenology, v.59, p.651-674, 2003.

NELDER, J.A.; MEAD, R. A simplex method for function minimization. The Computer Journal, v.7, p.308-313, 1965.
OSTERGAARD, S.; FRIGGENS, N.C.; CHAGUNDA, M.G.G. Technical and economic effects of an inline progesterone indicator in a dairy herd estimated by stochastic simulation. Theriogenology, v.64, p.819-843, 2005.

PRESS, W.H.; FLANNERY, B.P.; TEUKOLSKY, S.A.; VETTERLING, W.T. Numerical recipes in C: the art of scientific computing. New York: Cambridge University Press, 1990. $735 \mathrm{p}$

RUVUNA, F.; TAYLOR, J.F.; WALTER, J.P.; TURNER, J.W.; THALLMAN, R.M. Bioeconomic evaluation of embryo transfer in beef production systems. I.. description of a biological model for steer production. Journal of Animal Science, v.70, p.1077-1083, 1992a.

RUVUNA, F.; TAYLOR, J.F.; WALTER, J.P.; TURNER, J.W.; THALLMAN, R.M. Bioeconomic evaluation of embryo transfer in beef production systems. II. Economic evaluation of steer production. Journal of Animal Science, v.70, p.1084-1090, $1992 b$

RUVUNA, F.; TAYLOR, J.F.; WALTER, J.P.; TURNER, J.W.; THALLMAN, R.M. Bioeconomic evaluation of embryo transfer in beef production systems. III. Embryo lines for producing bulls. Journal of Animal Science, v.70, p.1091-1097, 1992c.

SLENNING, B. D.; WHEELER, M.B. Risk evaluation for bovine embryo transfer services using computer simulation and economic decision theory. Theriogenology, v.31, p.653-673, 1989.

VISINTIN, J.A.; ARRUDA, R.P.D.; MADUREIRA, E.H.; MIZUTA, K.; CELEGHINI, E.C.C.; ASSUMPÇÃO, M.E.O.D.; GUSMÕES, P.P.G.; CANDINI, P.H. Superovulação de novilhas da raça Nelore com diferentes doses de FSH/LH e congelação de embriões pelo método one-step com etilenoglicol. Brazilian Journal of Veterinary Research and Animal Science, v.36, p.267272, 1999.

WALSH, G.R. Methods of optimization. Chichester: John Wiley, 1979. $219 \mathrm{p}$.

Received March 03, 2008

Accepted December 15, 2008 